\title{
Opinião
}

\section{EDUCAÇÃO POSITIVA E IMPOSITIVA}

Cláudia Maria de Moura Pierre (1)

O processo educativo faz parte de toda nossa vida, necessariamente, na condição de criança e de adulto. Somos, em um só tempo, educandos e educadores. Versar sobre educação é versar sobre algo que já sabemos, porque viver é conhecer, é saborear, sapere. A modelação recíproca do ensino e aprendizagem é vivida continuamente por todos nós.

As posturas adotadas no ato educativo são apenas duas: ou se concebe o ato de educar como indução, ou como edução. Cada noção de educação é acompanhada por uma atitude que lhe corresponde.

A noção mais corriqueira adotada por pais e professores é de que a educação consiste num processo de instrução, injeção e modelagem do outro. Trata-se de uma distorção sobre o que consiste o ato de educar.

Grande parte dos adultos exerce uma arrogância ao acreditar que tem apenas que ensinar e nada a aprender com as crianças. Ele parte de uma pretensão cognitiva de que sabe tudo e que as crianças não ensinam. Isso resulta em uma negação do outro. Anula-se suas experiências e bagagens, suas descobertas e inovações. Os adultos passam a ditar para o outro como ele deve ser. Esta não é uma postura baseada na aceitação, mas na imposição de comportamentos.

Nestes moldes, acontece a educação bancária elucidada por Paulo Freire, no qual o adulto/professor vai fazendo depósitos de conteúdos nas cabeças dos alunos - acreditando-se que isto é possível.

Ao sermos criados num ambiente assim, perdemos a espontaneidade, pois é proibido ser quem é, mas deve-se ser do jeito que o outro especificou, de modo a atendê-lo. Assim sendo, o outro é quem determina nosso comportamento e como devemos ser. A autonomia e liberdade são cerceadas. É uma educação que tem a negação como fundamento. A negação ocorre ou por repressão ou por negligência 
Desta maneira, a criança cresce no medo. Medo de ser quem ela é. Não se sente à vontade de expressar seu ser. As repercussões são muitas: medo de falar em público, de se expor, de agir com naturalidade. As manifestações de seu ser são fundadas no medo. E cresce sentindo-se culpada. O raciocínio é: 'se não me aceitam como sou, deve ter algo errado comigo'. E passa a se culpar, simplesmente, por ser quem é.

Esta forma de 'educar' nada mais é do que falta de aceitação do outro, de amorosidade. Numa 'educação' realizada nestes moldes não há possibilidade de haver diálogo, pois educação dialógica implica em igualdade de condição, de consideração pela legitimidade do outro.

Em se tratando da educação formal, verifica-se que a dinâmica escolar consiste num apelo à obediência e as atividades ali desenvolvidas consistem em poucas práticas criativas e muito conteúdo e informação, que serão logo ultrapassados.

A concepção de educação - como injeção de conteúdo e de dever-ser, é uma moldagem a partir de fora. É uma violência à verdade que cada um traz consigo. Esta forma de 'educar' traz em seu bojo a noção de obediência que é uma relação de poder, também baseada na desigualdade e no medo, no qual ao obedecer, o outro tem que negar a si mesmo a fim de satisfazer os desejos e aspirações do outro - pais ou professores, sob pena de ser negado.

Educar numa forma de interação pautado no respeito e autoridade e não na obediência e no autoritarismo é difícil para nós, porque há séculos vivemos numa cultura na qual até nossa espiritualidade está condicionada à obediência às leis mosaicas e no temor a Deus. Ao invés de obediência, poderíamos tentar entrar em comunhão, ao invés de temor, poderíamos ser um canal do amor divino.

Etimologicamente, a palavra educar vem do latim educere, que quer dizer eduzir, conduzir para fora. Desenvolver o que já existe na pessoa, de forma latente. Só podemos desenvolver o que potencialmente já existe, como afirma o filósofo-educador Huberto Rohden. É como uma semente que se transforma em árvore. Desenvolver: des significa não, envolver, significa manter incluso, trancado. Educar é criar condições para que o outro possa se desenvolver livremente, na convivência conosco.

Como não podemos abrir a cabeça do outro e colocar coisas dentro, (embora muitos pensem que se processe assim), a educação consiste em partilhar espaços de convivência onde o outro se sinta à vontade para ser ele mesmo, para expandir-se. Não modelamos o outro, mas nos modulamos reciprocamente. Esta é a educação positiva, ou apenas, a educação. O processo educacional positivo - ou amoroso - consiste em gerar condições favoráveis para que o outro possa conviver conosco sem violentar seu ser. 
Das duas concepções de educação, uma implica em aceitar o outro ou, simplesmente amar. Neste tipo de convivência amorosa, a criança passa a acreditar em si, porque o que ela expressa é válido, é considerado. Ela se forma como um ser seguro e autônomo, o que não é de pouca importância. A outra concepção de educação, a impositiva, implica em tentar moldar o outro segundo padrões estabelecidos, e na exigência de que seja de certa maneira. Há uma imposição de condutas.

Educação impositiva é um erro de linguagem, ou há a educação verdadeira ou, verdadeiramente, não há educação.

\section{Sobre a autora:}

(1) Cláudia Maria moura Pierre é Mestre em Sociologia e Professora Adjunta do departamento de Ciências Sociais da Universidade Regional do Cariri - URCA. Crato-CE.

E-mail: claudiampierre@gmail.com

\section{Como citar este artigo (Formato ISO):}

PIERRE, Cláudia M.M. Educação Positiva e Impositiva. Id on Line Revista de Psicologia, Novembro de 2009, vol.1, no.10, p.13-15. ISSN 1981-1189. 